\title{
Predicting Vowel Systems: An Acoustic Analysis of the Vowels of Mebêngôkre and Panará
}

\author{
Myriam Lapierre \\ University of Ottawa
}

\section{Introduction}

A number of theories have been developed in order to generalize and predict how vowel systems are organized in the languages of the world. Some of the most influential theories of vowel systems that have been proposed are the Theory of Adaptive Dispersion (Liljencrants \& Lindblom 1972, Lindblom \& Engstrand 1989, Lindblom 1990), the Dispersion Theory of Contrast (Flemming 1996, 2004, 2006), and the Dispersion-Focalization Theory of vowel systems (Schwartz et al. 1997a). These theories have generally been successful in accounting for the organization of oral vowel systems; however, it is not fully understood whether they can successfully predict the organization of vowel systems that exploit a secondary articulatory dimension, such as nasality, laryngealization, or pharyngealization, among many others. Consequently, the goal of this paper is twofold. First, it will provide novel typological data on two severely understudied languages of the Jê family, namely Mebêngôkre and Panará, through a descriptive acoustic analysis of the oral and nasal vowels of the two languages. Second, it will determine whether the Dispersion-Focalization Theory of vowel systems (hereafter, DFT) is able to successfully predict the organization of the vowel systems of the two languages, with a particular focus on the predictions made for nasal vowel systems.

The structure of the paper is as follows: Section 1.1 presents basic information on the languages under study; section 1.2 discusses typological observations of nasal vowel systems that will be relevant to a discussion on theories of vowel systems; and section 1.3 presents a summary of some of the important aspects of the DFT. Section 2 presents the methodology that was followed to conduct the phonetic experiment. Section 3 presents results from the acoustic analysis. Section 4 compares the data from Mebêngôkre and Panará to the predictions made by the DFT. Section 5 discusses the implications of the results, and finally, the conclusions are presented in section 6 .

1.1 About Mebêngôkre and Panará Given the scarce representation of Jê languages in the linguistics literature, this section presents basic genetic and typological information on Mebêngôkre and Panará. Both languages are spoken in the eastern part of the Brazilian Amazon: Mebêngôkre is spoken in a few indigenous villages in the states of Pará and Mato Grosso, while Panará is spoken around the border between Pará and Mato Grosso. Figure 1 provides the internal organization of the Jê language family.

There are two main dialects of Mebêngôkre that are spoken by two distinct nations, namely the Kayapó and the Xikrín. The divide between the Kayapó and the Xikrín happened approximately two hundred years ago, and the differences between the two dialects are minimal (Salanova 2001). According to a 2010 census, there were 8,638 Kayapó and 1,818 Xikrín in 2010 (Instituto Socioambiental 2015).

The speakers of Panará belong to a single linguistically homogeneous nation, and its recent history does not involve important divisions. However, it is important to note that, following a dramatic population loss in 1974 that brought the number of Panará speakers down from approximately 600 to only 67 in a

\footnotetext{
*I would like to thank my language consultants from the communities of Djudjêkô and Nãsepotiti, who have allowed me to learn and study their language. I would also like to thank Andrés Salanova, Bernat Bardagil Mas, Marc Brunelle, Félix Desmeules-Trudel, Kevin McMullin, Jean-Christophe Leclerc, Michèle Burkholder, Santa Vīnerte, Claire Lesage, Luciana Storto, members of the Ottawa-Carleton phonology discussion group, and the audiences of MOLT 2015 (especially Christina Bjorndahl) and AMP 2015 for their time and valuable comments on this paper. All remaining errors are my own. This paper would also not have been possible without the financial support of the Social Sciences and Humanities Research Council of Canada, the Mitacs Globalink Research Award program, and the Faculty of Arts of the University of Ottawa.
}

(C) 2016 Myriam Lapierre

Proceedings of $A M P 2015$

Completed April 4, 2016 
matter of a year (Schwartzman 1987), members of different villages regrouped in a single village as a survival strategy. The current speakers of Panará are the descendants of members of these different villages, and there may be remnants of small dialectal differences in the language that they speak today.

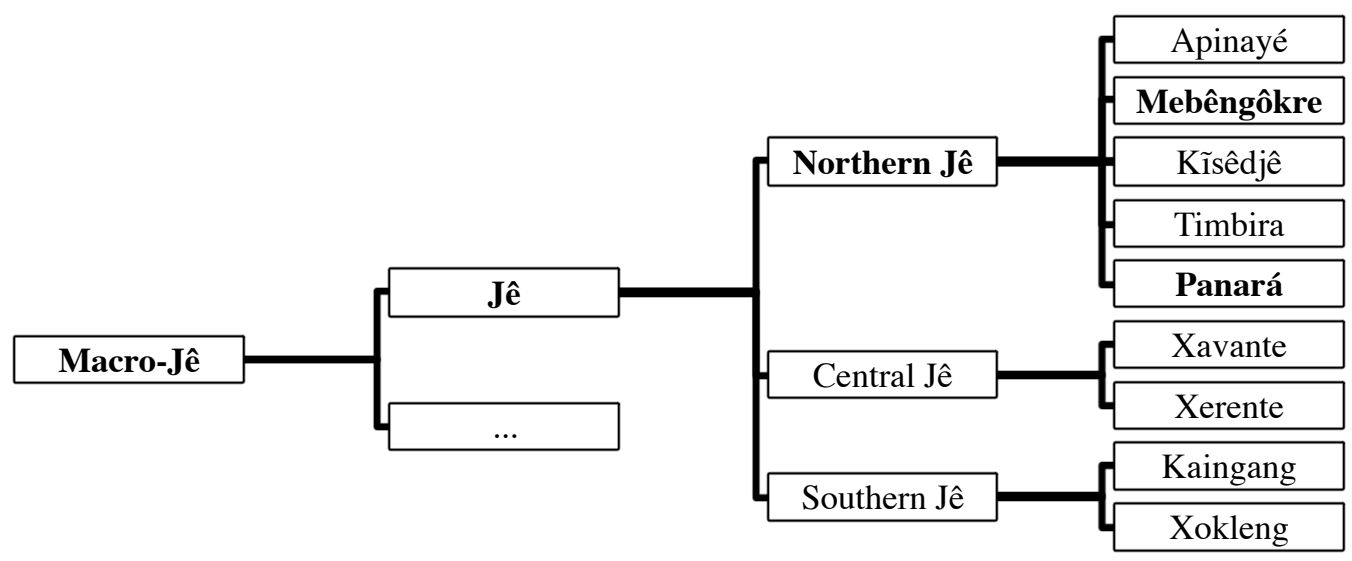

Figure 1: Internal organization of the Jê language family (adapted from Salanova 2001)

Jê languages are known for their extensive vowel systems, which include a large number of contrastive nasal vowels, and Mebêngôkre and Panará are no exceptions. Mebêngôkre has a total of 17 vowels (10 oral and 7 nasal), while Panará has a total of 15 vowels (9 oral and 6 nasal). Figure 2 provides the vowel inventories of the two languages.

\begin{tabular}{|c|c|c|c|c|c|}
\hline \multicolumn{6}{|c|}{ Mebêngôkre (17) } \\
\hline \multicolumn{3}{|c|}{ Oral (10) } & \multicolumn{3}{|c|}{ Nasal (7) } \\
\hline $\mathrm{i}$ & $\dot{\mathrm{i}}$ & $\mathrm{u}$ & $\tilde{\mathbf{l}}$ & $\tilde{\mathbf{t}}$ & $\tilde{\mathrm{u}}$ \\
\hline $\mathrm{e}$ & 9 & 0 & $\tilde{\mathrm{e}}$ & & $\tilde{0}$ \\
\hline$\varepsilon$ & $\Lambda$ & J & & $\tilde{\Lambda}$ & \\
\hline & $\mathrm{a}$ & & & $\tilde{a}$ & \\
\hline
\end{tabular}

\begin{tabular}{|c|c|c|c|c|c|}
\hline \multicolumn{6}{|c|}{ Panará (15) } \\
\hline \multicolumn{3}{|c|}{ Oral (9) } & \multicolumn{3}{|c|}{ Nasal (6) } \\
\hline $\mathrm{i}$ & $\dot{\mathfrak{t}}$ & $\mathrm{u}$ & $\tilde{\mathbf{l}}$ & $\tilde{\mathbf{t}}$ & $\tilde{\mathrm{u}}$ \\
\hline $\mathrm{e}$ & Ә & 0 & $\tilde{\mathrm{e}}$ & ã & $\tilde{0}$ \\
\hline$\varepsilon$ & $\mathrm{a}$ & J & & & \\
\hline
\end{tabular}

Figure 2: Vowel inventories of Mebêngôkre (adapted from Salanova \& Reis Silva 2010, Salanova 2001, Stout \& Thompson 1974) and Panará (adapted from Dourado 2001)

Given the unusually large vowel inventories found in Jê languages, Mebêngôkre and Panará provide data that is particularly well suited for testing the predictions made by a theory of vowel systems. In addition, the data from Mebêngôkre and Panará allows for comparison between two sister languages, which will contribute to a better typological understanding of the Jê family. The data may also provide some insight into the evolution of the phonology of Mebêngôkre and Panará and be of use to work on a reconstruction of the common ancestor of the two languages. Section 3.3 briefly considers how the data at hand may serve in a comparative study of Jê languages.

1.2 The typology of vowel nasality Nasality introduces significant changes to the organization of a vowel system, both from an acoustic and an articulatory point of view. This is a well-established fact that has been observed in a large number of languages (Beddor 1982, Beddor et al. 1986), and any theory of vowel systems should account for these observations in its predictions. From an acoustic perspective, nasal vowels tend to present an overall compression of the acoustic space in comparison to oral vowels. Specifically, the following changes have been observed: a decrease in the value of F1 for low vowels, an increase in the value of F1 for high vowels, and a decrease in the value of F2 for front vowels. Crucially, nasal vowel systems tend to present more phonemic contrasts in the F2 than in the F1 dimension, while the inverse pattern is observed for oral vowels (Kingston 2007). 
Evidence from articulatory studies of nasal vowels further support the fact that oral and nasal vowels are different. In the case of languages with phonologically nasal vowels, such as French, speakers appear to enhance the acoustic properties of vowel nasality through changes in the oral component of the articulation of nasal vowels (Carignan 2014, Carignan et al. 2015). In the case of languages where vowel nasality is not contrastive, such as American English, speakers appear to counteract the perceived acoustic effects of nasality by modifying the oral cavity configuration of nasalized vowels (Carignan et al. 2011). Because of the important differences in the acoustic, articulatory, and perceptual properties of nasal vowels in comparison to oral vowels, the present paper will assume that there is no clear synchronic oral-nasal vowel counterpart relationship in languages where vowel nasality has undergone phonologization, unless otherwise motivated by phonological processes in a given language.

The novel data from Mebêngôkre and Panará presented in this paper will allow for comparison between the acoustic properties of oral and nasal vowels in the two languages. Furthermore, this data will serve to test the predictions made by the DFT for the organization of oral and nasal vowel systems separately, a task which has not been undertaken by any previous studies.

1.3 Overview of the Dispersion-Focalization Theory of vowel systems The DFT is an acoustic theory of vowel systems, which makes it particularly well suited for an analysis of the acoustic data at hand. The theory integrates the basic ideas of the Adaptive Dispersion Theory and Quantal Theory (Stevens 1972, 1989), and it was formalized by taking into account a number of crosslinguistic tendencies in vowel inventories (Schwartz et al. 1997b). These major trends were determined by conducting a thorough analysis of the UCLA Phonological Segment Inventory Database (UPSID, Maddieson 1984). The DFT is generally concerned with predicting the organization of optimal vowel systems, defined as the most common configurations of vowel inventories found in UPSID. It predicts the organization of vowel systems according to two perceptual parameters: $\lambda$ (global dispersion) and $\alpha$ (local focalization), which function as independent variables in the system, with values ranging from 0 to 1 .

Global dispersion is a property of a vowel in relation to other vowels in a system. It refers to the distance between vowels within the acoustic space, such that vowels in a given inventory are maximally distinct from one another. Local focalization is an individual property of every vowel, and refers to the proximity of the formants in the spectrum of one given vowel. For example, /i/ is more focal than /e/, because the values of F2 and F3 for /i/ are closer to one another than they are for /e/. Because formant convergence seems to result in increased perceptual salience, $/ \mathrm{i} /$ is more common in vowel systems than /e/.

Increasing $\lambda$ disfavors mid vowels, which results in a maximal number of high and low vowels, while decreasing $\lambda$ favors peripheral vowels. A minimal value of $\lambda$ results in a vertical vowel system, in which the number of contrasts in the F1 dimension is maximized, while a maximal value of $\lambda$ results in a minimal number of contrasts along the F1 dimension. Increasing $\alpha$ favors focal vowels, while decreasing $\alpha$ disfavors them. According to Schwartz et al. (1997a), "[f]ocalization favors first /i/ and /y/, then front unrounded vowels with the highest focalization benefit for the highest vowels, and finally back unrounded vowels." Systems with an approximately equal value of both $\lambda$ and $\alpha$ are those that show the most peripheral and symmetrical systems.

Finally, the DFT also takes the number of segments in the inventory into consideration when predicting the organization of a system. Specifically, a larger number of segments in the inventory results in a more crowded system around the peripheries of the acoustic space. For a complete review of the DFT and its predictions, please refer to the original article (Schwartz et al. 1997a).

\section{Methodology}

2.1 Participants Twelve male speakers of Mebêngôkre and twelve male speakers of Panará participated in this study. All of the Mebêngôkre speakers resided in the village of Djudjêkô, one of the three villages inside the Xikríns of the Cateté Indigenous Reserve, at the time that the study was conducted. The sample of Mebêngôkre speakers included individuals between the ages of 18 and 47 (mean=29). All Panará speakers resided in the village of Nãsepotiti, located on the Panará Indigenous Reserve, and the sample of Panará speakers included individuals between the ages of 22 and 45 (mean=31). Any individual who was a native speaker of Mebêngôkre or Panará and was between 18 to 47 years of age was considered eligible to participate in the experiment. 
The Xikrín and Panará populations are quite homogeneous in terms of socio-economic factors. There are indeed no clear divisions of social classes. The only social factor that may have influenced the results of the present study is the division between Kayapó and Xikrín speakers of Mebêngôkre in the village of Djudjêkô. Although Djudjêkô is a Xikrín village, some Kayapós have been integrated into the community and have been living there for several years. Note that five of the twelve Mebêngôkre speakers identified as Kayapó. Dialectal differences do exist; however, a previous statistical analysis (Lapierre 2015) has shown that there are no significant differences in the production of vowels between Xikrín and Kayapó speakers of Mebêngôkre. For this reason, members of both communities have been collapsed into a single group.

Participants had varying levels of proficiency in Brazilian Portuguese, ranging from advanced to no knowledge at all. Second language proficiency in Brazilian Portuguese is not expected to have an effect on the results of this experiment, because both Mebêngôkre and Panará are vital languages that are being transmitted to children as a native language, and speakers of Mebêngôkre and Panará feel more at ease when speaking their native language. Residents of Nãsepotiti are formally educated in both Panará and Portuguese and are therefore literate in both languages. Younger residents of Djudjêkô are formally educated in Portuguese and are able to read and write, but only few speakers of Mebêngôkre can also read and write in their native language. For this reason, the experiment was designed to accommodate both literate and illiterate speakers, as described in sections 2.2 and 2.3 .

2.2 Materials One target word was selected for every vowel quality in each language, which yielded a total of 17 target words for Mebêngôkre and 15 target words for Panará. All target words were monosyllabic and had a simple CV structure, where $\mathrm{C}$ is a bilabial stop and $\mathrm{V}$ is the target vowel. For illustration purposes, the following list provides some of the target words included in the Mebêngôkre version of the experiment: [pa] (arm), [mĩ] (alligator), and [bõ] (grass). Only one Mebêngôkre word did not

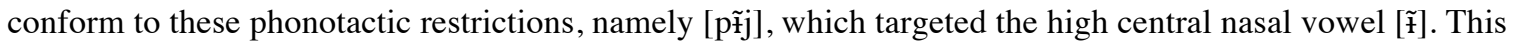
word containing a palatal glide in coda position was included in the experiment, because (1) the vowel [₹̃] has a very low frequency in the Mebêngôkre lexicon and no word matching the desired CV structure was found, and (2) an attempt was made to include a nonce-word matching the desired phonotactic structure, but native speaker consultants were left perplexed when asked to produce a nonce-word containing the vowel [ĩ]. Furthermore, an effort was made to include highly imageable words, although this was not possible for all vowel qualities, given the low frequency of some vowels in the lexicons of the two languages. The researcher worked alongside native speaker consultants in an effort to find the best visual representation of every target word.

A carrier phrase with the meaning "I say the word [X]" was selected in each language (Mebêngôkre [SOV]: Ba [X] bit jarẽ ; Panará [SVO]: I $k j \tilde{e} ~ h \tilde{e} k a$ sũ [X]). Finally, five practice items were included in each language in order for the participants to get familiarized with the task before beginning the experiment.

2.3 Procedure All recordings were produced in the villages of Djudjêkô and Nãsepotiti during the summer of 2015 using a Zoom H4n recorder and a Yoga HM-20 unidirectional headset microphone with a sampling rate of $44.1 \mathrm{kHz}$. Each target word was presented visually on an individual slide in a PowerPoint presentation so as to eliminate the risk of creating an enumeration effect on prosody. Words within their carrier phrases were presented in standard orthography alongside a picture in order to help the illiterate participants identify the target words. Note that all vowel phonemes are associated to different graphemes

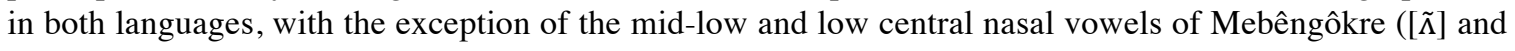
[ã]), which are both written as $\tilde{a}$.

As even the literate participants do not read in a fluid manner representative of natural speech, the researcher guided the participants through the task by producing the entire carrier phrase for every token, and participants were asked to simply repeat what had been said. This was done to reduce the complexity of the task, as participants were not familiar with experimental designs, and this method allowed them to feel more at ease. Although the researcher was not a native speaker of Mebêngôkre or Panará, she is a trained phonetician who has invested a significant amount of time practicing each vowel quality with native speakers. The researcher was able to produce each vowel quality distinctively, and a pilot test of the experiment was run with native speaker consultants before beginning the data collection. Native speakers did not show any difficulty in identifying the target vowels during the experiment, and pictures provided additional information that served to facilitate the task. 
Each target word was presented a total of ten times in semi-randomized blocks. Speakers received 175 grams of Czech beads as compensation for participating in the experiment.

2.4 Corpus and data Each of the 24 participants produced a recording consisting of ten tokens of each target vowel, resulting in a corpus of 4,320 tokens, 2,040 for Mebêngôkre, and 2,280 for Panará. A total of 19 tokens were discarded (13 for Mebêngôkre, and 6 for Panará) due to background noise, hesitations, or use of a deviating intonation contour.

\section{Results of the acoustic analysis}

The goal of the acoustic analysis is to determine the values of F1 and F2 for each one of the vowel phonemes of Mebêngôkre and Panará in order to see where each of the vowels is situated within the acoustic space. This data will serve to test the predictions made by the DFT (section 4). In order to do this, the values of the first two vowel formants were extracted for each token in the corpus at $25 \%$ of the duration from vowel onset. The $25 \%$ duration point was preferred over the standard $50 \%$, as target words appeared in sentence-final position in Panará, and this often resulted in reduced amplitude and devoicing of the target vowels, beginning at approximately $50 \%$ of vowel duration. In an effort to maximize comparability of the results between the two languages, the same time point was selected for formant extraction in both languages. A Praat script was used as a first step to extracting the formant values, set to identify four formants within the first $4.5 \mathrm{kHz}$. All of the high back oral vowel tokens were then manually verified, as well as all of the nasal vowel tokens, and any other token for which the formant values obtained from the output of the script were dubious. Finally, the vowels were plotted on the F1-F2 planes. These results are presented separately for oral and nasal vowels in Figures 3-6, first for Mebêngôkre, and then for Panará. Note that the values for the vowel formants have not been normalized in order to facilitate the comparison between these results and the predictions made by the DFT, which uses raw $\mathrm{Hz}$ values.

\subsection{Mebêngôkre data}

3.1.1 Oral vowels The ten oral vowels of Mebêngôkre can be described as three front, four central, and three back vowels; and as three high, three mid-high, three mid-low, and one low vowel. While some overlap of the token clouds is normal, there is significant overlap of the central vowels. Specifically, it appears that the high central vowel /i/ overlaps completely with the mid central vowel/s/. This suggests that the mid central vowel may be undergoing a merger with the high central vowel, or that these two phonemes may be differentiated on another phonetic dimension.

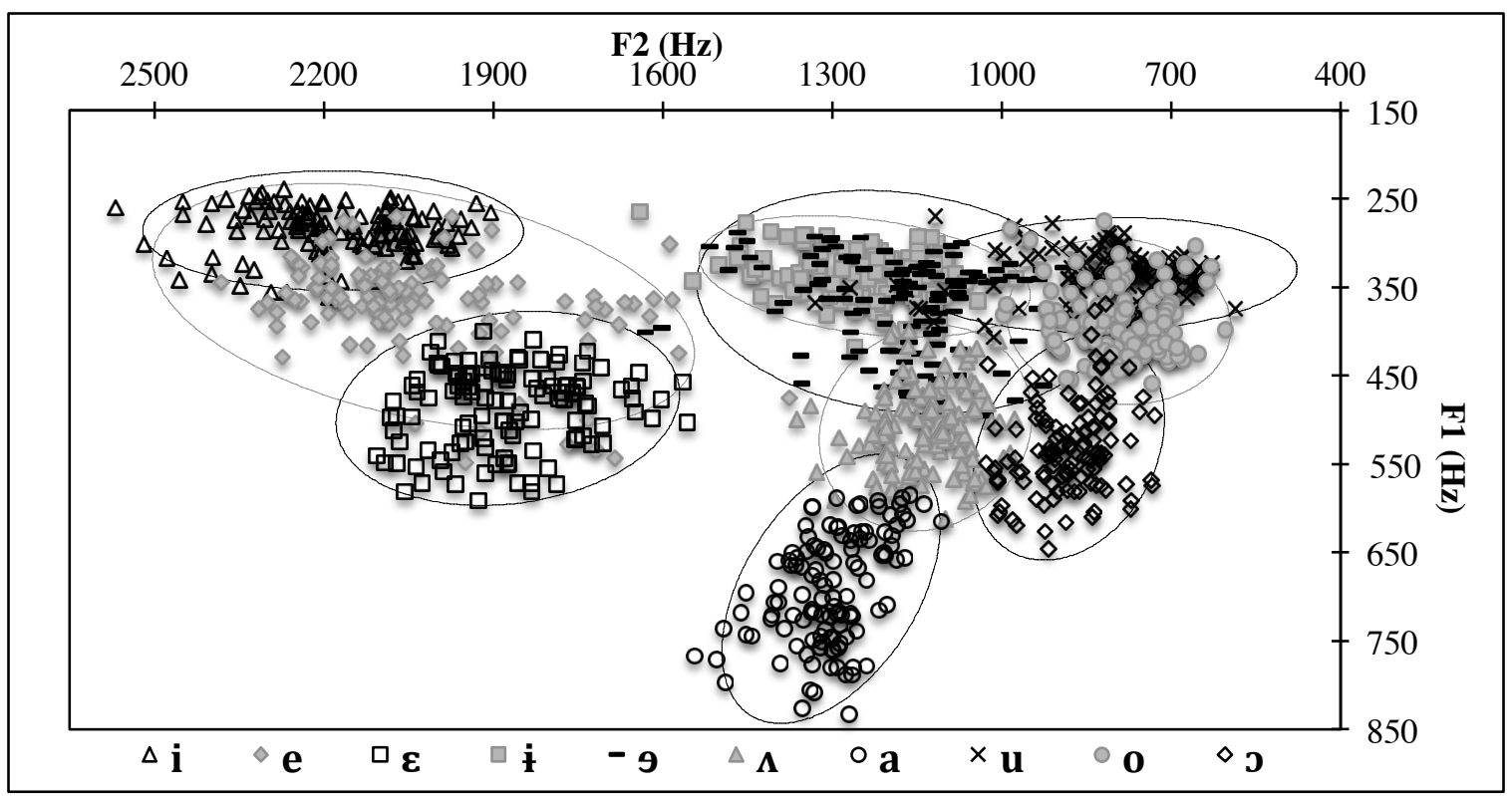

Figure 3: F1-F2 plane of Mebêngôkre oral vowels with 95\% confidence ellipses 
3.1.2 Nasal vowels The seven nasal vowels of Mebêngôkre can be described as two front, three central, and two back vowels; and as three high, three mid, and one low vowel. As in the case of the oral vowels, there is significant overlap of the central nasal vowels. There is a complete overlap of the distribution of the mid-low nasal vowel $/ \tilde{\Lambda} /$ and the low nasal vowel /ã/. Given that the low nasal vowel is very rare in the Mebêngôkre lexicon, and that it only occurs in the vicinity of nasal consonants, it may be that this low nasal vowel is not in fact a distinct phoneme, or that it has merged with the mid central nasal vowel.

Furthermore, in comparison to the acoustic space for oral vowels, that of the nasal vowels seems significantly reduced, and this reduction is most prominent in the F1 dimension. Indeed, a whole level of height contrast has been eliminated: It appears that there is no true low vowel in the nasal vowel inventory of Mebêngôkre, as no vowel token had a value of F1 exceeding $623 \mathrm{~Hz}$.

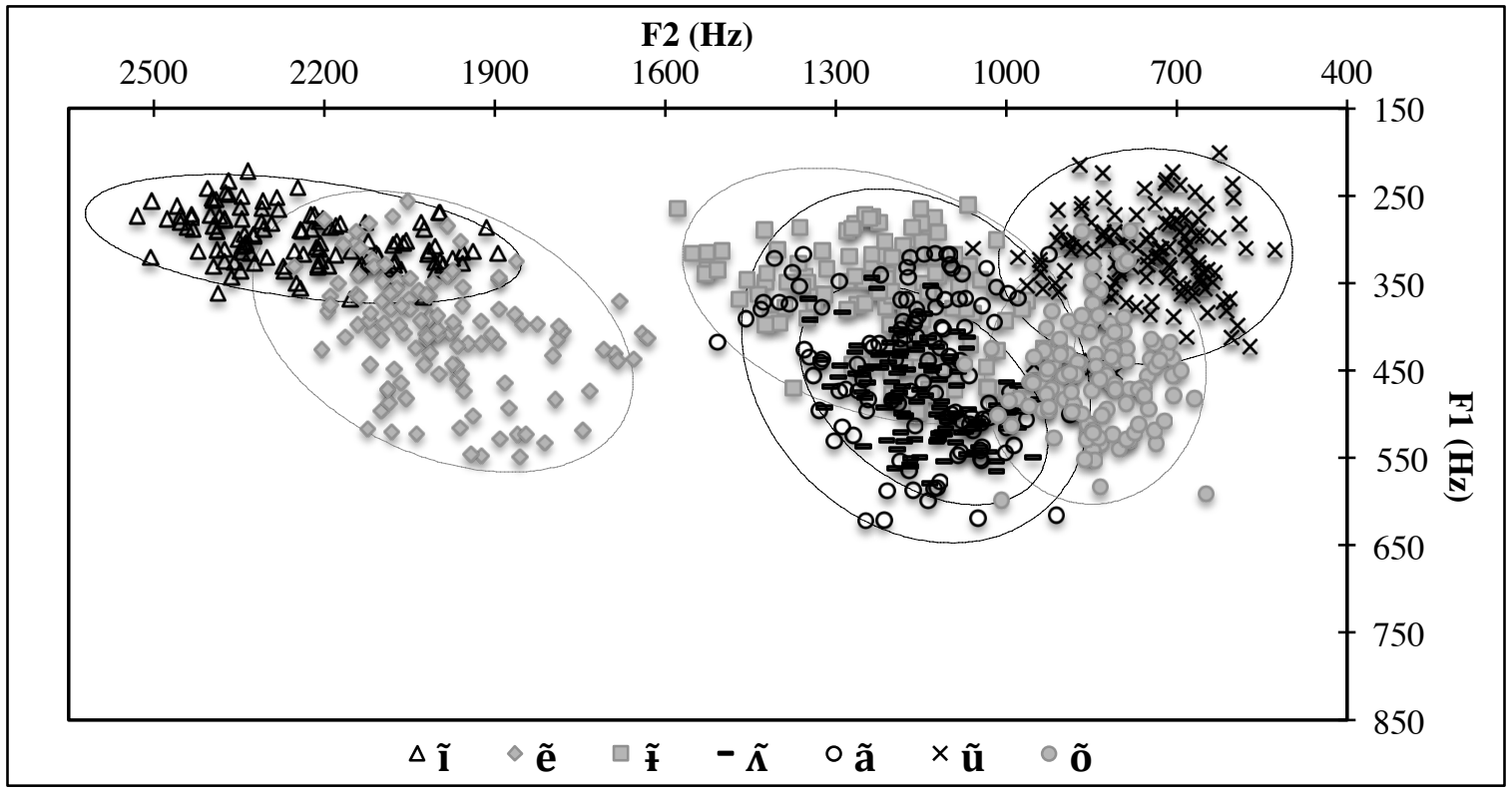

Figure 4: F1-F2 plane of Mebêngôkre nasal vowels with 95\% confidence ellipses

\subsection{Panará data}

3.2.1 Oral vowels Panará's nine oral vowels are divided into three front, three central and three back vowels; and into three high, three mid-high, two mid-low and one low vowel. Unlike the oral vowels of Mebêngôkre, the less significant overlap in the oral vowels of Panará does not suggest any ongoing merger of the central vowels. 


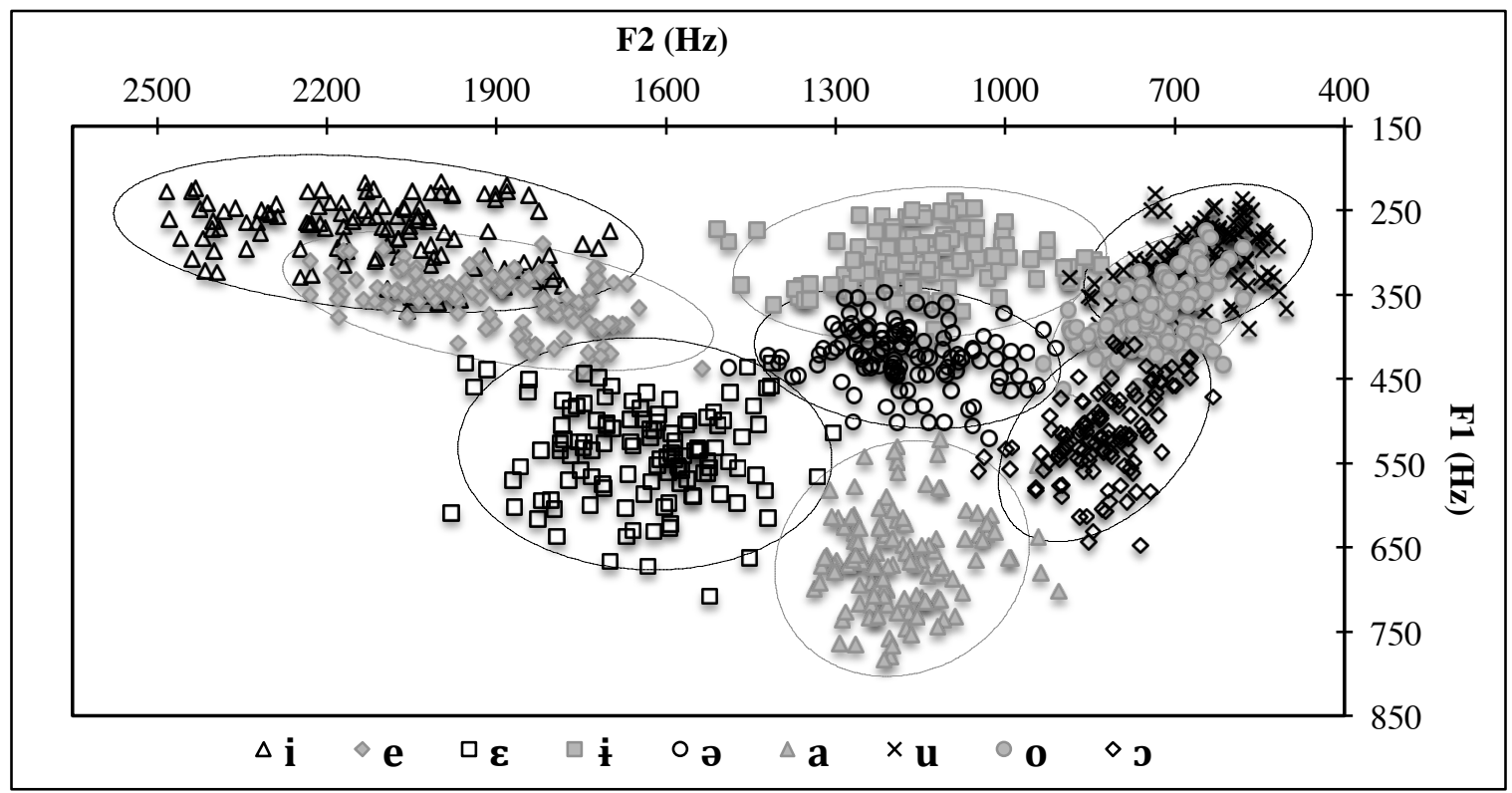

Figure 5: F1-F2 plane of Panará oral vowels with $95 \%$ confidence ellipses

3.2.2 Nasal vowels The six nasal vowels of Panará can be described as two front, two central and two back vowels; and as three high and three mid vowels. Specifically, the low nasal vowel /ã/ patterns with the mid vowels /ẽ/ and /õ/ in terms of height. There does not appear to be a true low nasal vowel in Panará, and, just as in Mebêngôkre, the acoustic space for nasal vowels appears contracted in the F1 dimension when compared to the acoustic space of oral vowels. As in the case of Mebêngôkre, it appears that there is no true low nasal vowel in Panará, as no vowel token had a value of F1 exceeding $618 \mathrm{~Hz}$.

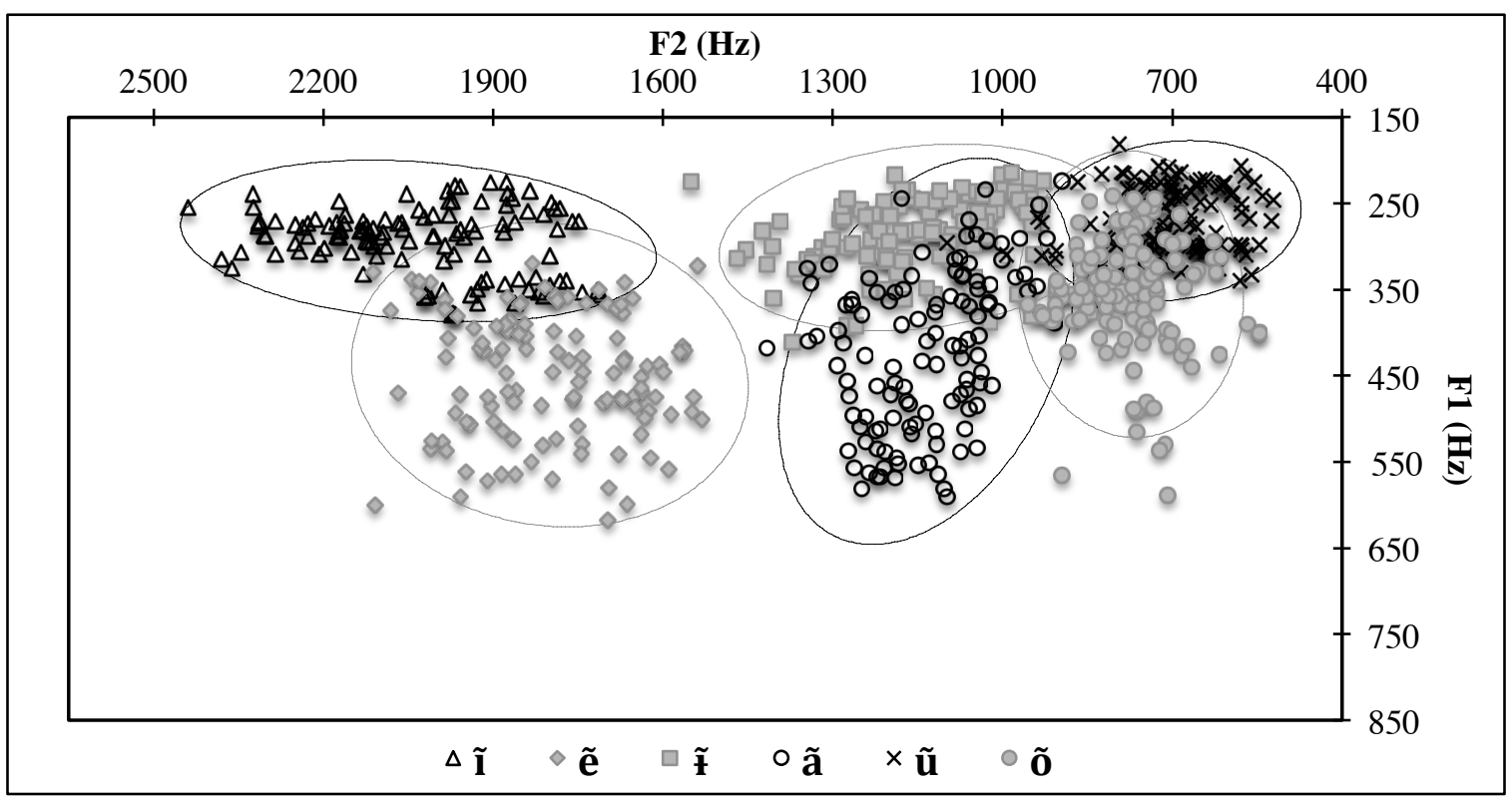

Figure 6: F1-F2 plane of Panará nasal vowels with 95\% confidence ellipses 


\subsection{Cross-language comparison}

3.3.1 Oral vowels The oral vowel inventories of Mebêngôkre and Panará are nearly identical, with the exception of a difference in the number of height contrasts for central vowels: Where Panará has only three height contrasts, Mebêngôkre has four. Panará's mid central vowel /ə/ is distributed over the same acoustic space as Mebêngôkre's mid-high $/ 9 /$ and mid-low $/ \mathrm{N} /$ central vowels, which suggests that these two oral vowels may have merged into a single mid central vowel in Panará.

Given the differences in the number of height contrasts in the central vowels of Mebêngôkre and Panará, there seem to be two plausible hypotheses regarding the inventory of oral vowels of ProtoNorthern-Jê (hereafter PNJ, the common ancestor of the two languages): (1) PNJ had four height contrasts for central vowels, like Mebêngôkre; and (2) PNJ had three height contrasts for central vowels, like Panará. If hypothesis (1) is correct, then the mid-high and mid-low central vowels of PNJ must have merged into one vowel in Panará. If hypothesis (2) is correct, then the mid central vowel of PNJ must have divided into a mid-high and a mid-low central vowel in Mebêngôkre.

Hypothesis (1) is supported by the results of a perceptual discrimination task conducted by Storto and Demolin (2002). This experiment showed that Karitiâna speakers were significantly worse at identifying central vowels, even when these sounds are contrastive in the phonological inventory of their native language. From the results of this study, it can be hypothesized that central vowels are less perceptually salient than peripheral vowels, and that a merger of two mid central vowels is more likely to occur than a split. Given that phonological changes are often phonetically natural (Hayes 1999, Solé 2012), hypothesis (1) seems more plausible. As was noted in section 3.1.1, a similar merging process may be underway in Mebêngôkre, as the mid-high central vowel/s/ overlaps significantly with the high central vowel /it/.

3.3.2 Nasal vowels Mebêngôkre is described as having an additional nasal vowel in comparison to Panará. However, this extra low nasal vowel patterns in the same way as the mid-low nasal vowel, suggesting that such a contrast may not actually exist. In fact, this contrast is not reflected in the orthography of Mebêngôkre, as was briefly mentioned in section 2.2. It may be the case, however, that the differences between these two vowels were simply not captured by the present analysis, as it may be the case that the phonological contrast between the low and mid-low nasal vowels is manifested through another phonetic dimension (e.g. F3). However, it is impossible to claim, at this point, whether Mebêngôkre truly has a low nasal vowel that contrasts with a mid-low nasal vowel. The results of this experiment suggest that the nasal vowel inventories of Mebêngôkre and Panará are organized identically. Crucially, both Mebêngôkre and Panará lack a true low nasal vowel, as the F1 values of the low nasal vowels of both languages are more similar to those of the mid-vowels (/ẽ, õ/) than to those of the low oral vowels. In addition, both Mebêngôkre and Panará nasal vowels present a larger number of contrasts in the F2 dimension (three) than in the F1 dimension (two), which is consistent with data from nasal vowel inventories observed in other languages (Beddor 1982; Kingston 2007).

\section{Testing the predictions of the DFT}

4.1 Oral vowels First, it is important to note that Schwartz et al. (1997a) offer no simulations for the organization of vowel systems containing nine segments (such as Panará's oral vowel inventory) or ten segments (such as Mebêngôkre's oral vowel inventory) in their paper presenting the DFT. Figure 7 presents DFT simulations for systems of six and seven vowels (the maximum provided), based on different values of $\lambda$ and $\alpha$ that result in different vowel configurations.

As the theory's predictions for nine or ten vowel systems are not explicitly stated, the task of comparing the theory's predictions to the data from Mebêngôkre and Panará is one that yields relatively unclear results. That said, the data from Mebêngôkre and Panará's oral vowel systems is consistent with the most common vowel systems observed in UPSID for systems of nine or ten phonemes, as reported in Schwartz et al. (1997b). In order for the DFT to yield a nine or ten vowel system with the characteristics of the systems found in Mebêngôkre or Panará, the values of $\alpha$ and $\lambda$ must be manipulated.

First, the value of $\alpha$ must be set quite low (around 0.1 or 0.2 ) so as to avoid the emergence of focal vowels, which would result in a series of front rounded vowels that are not observed in Mebêngôkre or Panará. Furthermore, the value of $\lambda$ must be set at approximately 0.5 in order to avoid both a vertical system as well as a system in which mid vowels are dispreferred. These approximate weights of $\alpha$ and $\lambda$ should yield a system of nine vowels like Panará's oral vowel system, and a system of ten vowels like 
Mebêngôkre's oral vowel system. In sum, the predictions of the DFT align closely with the data observed from the oral vowels of both Mebêngôkre and Panará.
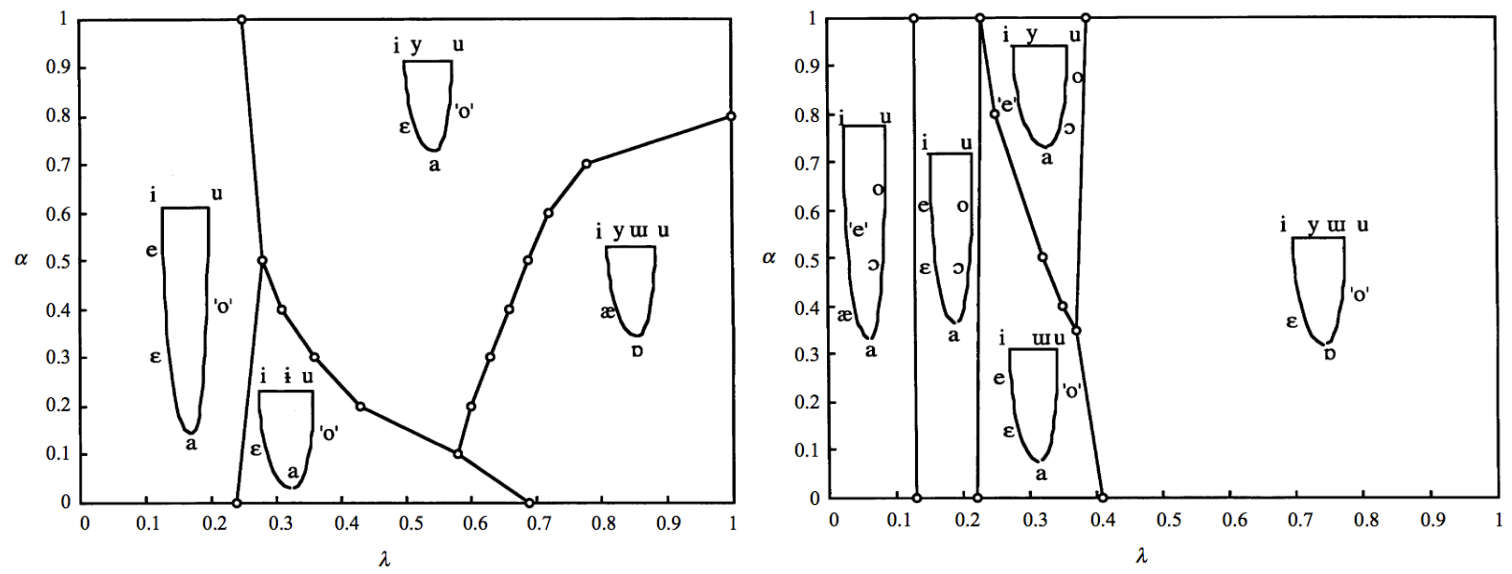

Figure 7: DFT simulations for six and seven vowel systems (from Schwartz et al. 1997a)

4.1.2 Nasal vowels Although the authors of the DFT make explicit distinctions for primary and secondary inventories in the major typological trends observed in UPSID and further note that "the nasal feature [...] leads to significant changes in the formant space and is likely to be processed on another dimension than the oral one" (Schwartz et al. 1997b), they do not make separate predictions for the organization of nasal vowel systems in the DFT (Schwartz et al. 1997a). For this reason, the nasal vowel systems of Mebêngôkre and Panará must be compared to the DFT simulations made for oral vowel systems. The simulations for six and seven vowel systems, mentioned previously in the context of our discussion of the oral vowels, are presented in Figure 7.

Vertical vowel systems, which have a maximal number of contrasts along the F1 dimension, emerge when $\lambda$ is given a minimal value. Inversely, when $\lambda$ is given a maximal value, we observe systems with a large number of contrasts along the F2 dimension: Both the six and seven vowel configurations have four high vowels; the seven vowel system has only two mid vowels; and the six vowel system has no mid vowels at all. For six and seven vowel systems, the weight given to $\alpha$ will determine whether the third high vowel to emerge will be a front rounded or a central vowel (though note that in some cases it may also be a back unrounded vowel). A high value of $\alpha$ will favor focal vowels, such as front rounded vowels, while a low value of $\alpha$ will favor non-focal vowels, such as central vowels.

In order for the DFT to yield vowel systems that are most similar to those observed in Mebêngôkre and Panará's nasal vowel systems, the value of $\lambda$ must be set at approximately 0.5 so as to avoid the emergence of a vertical vowel system as well as one where mid vowels are dispreferred. Furthermore, the value of $\alpha$ must be set at approximately 0.1 or 0.2 so as to favor the emergence of a series of central vowels rather than a series of front rounded vowels. These values are the same as those given for the oral vowel systems of both Mebêngôkre and Panará in section 4.1.

Note, however, that all possible combinations of weight of $\alpha$ and $\lambda$ yield a low vowel. The data from Mebêngôkre and Panará presented in sections 3.1.2 and 3.2.2 showed that neither nasal vowel system has a true low vowel. For both languages, the low nasal vowel's F1 actually patterns with the mid vowels. Thus, no combination of $\alpha$ and $\lambda$ in the DFT can yield a system of six or seven segments organized identically to Mebêngôkre or Panará's nasal vowel systems, and the theory thus fails to predict the organization of both nasal vowel systems.

The DFT attempts to predict systems that are crosslinguistically optimal (according to UPSID, Schwartz et al. 1997b), while also allowing a number of sub-optimal vowel systems. The authors recognize that the DFT cannot account for some of these sub-optimal systems and that a number of other factors can come into play, such as sociolinguistic influences, diachronic evolutions, and interference with other phonological units. However, Mebêngôkre and Panará's nasal vowel systems are not examples of such sub- 
optimal systems, as they pattern in very similar ways to nasal vowel systems from other languages (Beddor 1982, Beddor et al. 1986) and furthermore seem very stable in the language family.

\section{Discussion}

5.1 The acoustic and perceptual correlates of vowel nasality The acoustic and perceptual correlates of nasality on vowels are particularly complex and remain, to this day, not fully understood (Beddor 1993, Maeda 1993). While the configuration of the oral cavity can be modified in a great number of ways that allow oral formants to vary in frequency, the nasal cavity cannot be modified. The only aspect of nasality that can be controlled by speakers is the degree of coupling of the oral and nasal cavities, which is regulated by the degree of opening of the velum.

Formants that result from the flux of air through the nasal cavity have relatively stable frequency values for each individual, unlike the oral formants, which depend on the articulatory configuration of the oral cavity. The anatomical configuration of the nasal cavity varies greatly among individuals, but the value of the first nasal formant ( $\mathrm{N} 1$, which is most relevant here) is generally found around $400 \mathrm{~Hz}$ to $500 \mathrm{~Hz}$ (Maeda 1993). Nasality manifests itself differently on every vowel, not because nasality itself is variable, but because it is superimposed on oral formants, which can vary greatly as a result of the many ways in which speakers can configure their oral cavity to produce vowels.

$\mathrm{N} 1$ is of a higher frequency than the F1 of high vowels and of a lower frequency than the F1 of low vowels. When N1 is in the vicinity of F1, they become perceptually merged (Beddor 1993, Maeda 1993, Schwartz et al. 1997b, Shosted et al. 2012, Carignan 2014), and F1 appears to have a wider bandwidth. The center of gravity of this area of high amplitude in the vowel spectrum is shifted toward N1. Specifically, this interaction of acoustics and perception causes high vowels to raise the center of gravity of F1, making the vowel sound lower. Inversely, the center of gravity of low vowels is perceived as lower, which has the effect of making the vowel sound higher. Experimental evidence suggests that this seemingly crosslinguistic acoustic-perceptual constraint on nasal vowels can be the trigger of sound change (Beddor et al. 1986). Over time, the shift in the center of gravity of nasal vowels can cause listeners to reinterpret the height of nasal vowels. This results in a general contraction of the acoustic vowel space that is most prominent in the F1 dimension, just as in the case of Mebêngôkre and Panará's nasal vowel inventories.

5.2 Implications While the fact that nasality in vowels often results in a reduction in the height dimension of the acoustic vowel space has been recognized in the literature by a number of authors (Beddor 1993, Maeda 1993, Schwartz et al. 1997b, Kingston 2007, Shosted et al. 2012, Carignan 2014) and can be explained satisfactorily by the acoustic approach described in section 5.1, this knowledge has yet to be integrated into a theory of vowel systems. The proponents of the DFT, as mentioned in section 4.3.2, do not make separate predictions for the organization of oral and nasal vowel systems. However, the DFT is successful at predicting the organization of the oral vowels of Mebêngôkre and Panará, along with data from a much larger sample of languages, as observed in the authors' survey paper (Schwartz et al. 1997b).

That said, the general mechanisms governing the organization of the nasal vowels of Mebêngôkre and Panará within the acoustic space appear to be the same as those active in the organization of oral vowel systems. Global dispersion $(\lambda)$ is a major contributing factor in determining the organization of nasal vowels within the acoustic space, as the nasal vowels of both Mebêngôkre and Panará are still dispersed among themselves within the available acoustic space. However, global dispersion is constrained in the height dimension, as the F1 values between approximately $650-850 \mathrm{~Hz}$ are, for a number of acoustic and perceptual reasons described in section 5.1, unavailable to the speakers of Mebêngôkre and Panará. If one accepts that nasal vowel inventories are constrained in the height dimension, then Mebêngôkre and Panará's oral and nasal vowel systems can be described using the same values of both $\alpha$ and $\lambda$.

It may seem that Mebêngôkre and Panará's nasal vowel systems resemble the vertical vowel systems described in section 1.3 and that the two languages' nasal vowel systems behave differently from the oral vowels with respect to the value of local focalization $(\alpha)$. However, this explanation is inadequate. Vertical vowel systems, which have a maximal number of contrasts along the F1 dimension, consist of a series of acoustically high and a series of acoustically low vowels. The proponents of the DFT provide approximate values in hertz for the F1 of high and low vowels, which are $277 \mathrm{~Hz}$ and 648-800 Hz respectively. As mentioned earlier, no true low vowel has been observed in the nasal vowel inventories of Mebêngôkre or Panará, precisely because the acoustic space between $650-850 \mathrm{~Hz}$ in the $\mathrm{F} 1$ dimension is unoccupied in 
both systems. Neither of the two vowel systems presented here, then, can be accounted for by increasing the value of $\alpha$.

I suggest that the acoustic space of phonologically nasal vowels is constrained in the F1 dimension. Accounting for this apparent restriction of the acoustic space available to nasal vowels is a small adjustment to the DFT that allows the general mechanisms of global dispersion and focalization to apply normally for nasal vowels, albeit in a reduced space. This prediction is consistent with the typological observations that (1) nasal vowel systems tend to present more contrasts in the F2 than in the F1 dimension, (2) nasal vowel inventories are often reduced in size in comparison to oral vowel inventories, and (3) nasal vowels never make up more than $50 \%$ of a language's vowel inventory (i.e., no language has more nasal vowels than oral vowels). All of these observations appear as natural consequences of a contracted acoustic space in the F1 dimension for nasal vowels.

The degree of constriction of F1 for nasal vowel systems varies from language to language, and I do not claim that the values of F1 between $650-850 \mathrm{~Hz}$ are unavailable to all nasal vowel systems. While this appears to be the case for Mebêngôkre and Panará, other languages may have a greater or a lesser degree of reduction of $\mathrm{F} 1$ as a result of various factors, including but not limited to different configurations of the articulators in the vocal tract during the production of nasal vowels, and language-specific diachronic processes. Acoustic space reduction for nasal vowels is the result of phonologization of nasality for vowels and is affected by a number of factors, such that different nasal vowel systems behave in fundamentally different ways.

\section{Conclusion}

This paper presented novel acoustic data on the vowels of Mebêngôkre and Panará, two languages of the Jê family spoken in the eastern Amazon. Careful review of the differences between the oral and nasal vowels of the two languages led to the observation that neither Mebêngôkre nor Panará has a true low nasal vowel, and that the acoustic space found approximately between $650-850 \mathrm{~Hz}$ in the F1 dimension was unavailable to the nasal vowels of the two languages. The predictions made by the DFT were presented, and it was shown that the theory was unable to account for the organization of the nasal vowel systems of Mebêngôkre and Panará. Finally, I proposed to constrain the acoustic space available in the F1 dimension for nasal vowels.

This modification of the DFT enables us to analyze oral and nasal vowel systems using the same mechanisms. Previous research on vowel systems has generally assumed that the mechanisms governing the organization of oral and nasal vowels were fundamentally different, which does not appear to be the case, as both global dispersion and local focalization seem to play a crucial role in the organization of both oral and nasal vowel systems.

Future research should focus on formalizing a way to predict the degree of reduction of the height dimension of nasal vowel acoustic space, which must be independently measured for every language. Progress in this line of research will allow for better comparisons between oral and nasal vowel systems and will provide a more cohesive theory of vowel systems.

\section{References}

BEDDOR, PATRICE S. 1982. Phonological and phonetic effects of nasalization on vowel height. University of Minnesota dissertation. [Reproduced by the Indiana University Linguistics Club, 1983])

Beddor, PATRICE S. 1993. The Perception of Nasal Vowels. In Huffman \& Krakow, 168-196.

Beddor, Patrice S.; Rena A. Krakow, and Louis M. Goldstein. 1987. Perceptual constraints and phonological change: A study of nasal vowel height. Phonology Yearbook 3.197-217.

CARignan, Christopher. 2014. An acoustic and articulatory examination of the 'oral' in 'nasal': The oral articulations of French nasal vowels are not arbitrary. Journal of Phonetics 46.23-33.

Carignan, Christopher; Ryan Shosted; Chilin ShiH; and Panying Rong. 2011. Compensatory articulation in American English nasalized vowels. Journal of Phonetics 39.668-682.

Carignan, Christopher; Ryan Shosted; Maojing Fu; Zhi-Pei Liang; and Bradley P. Sutton. 2015. A real-time MRI investigation of the role of lingual and pharyngeal articulation in the production of the nasal vowel system in French. Journal of Phonetics 50.34-51. 
Dourado, Luciana G. 2001. Aspectos morfossintáticos da língua Panará (Jê). São Paulo, Brazil: Universidade Estadual de Campinas dissertation.

FLEMming, EdWARD. 1996. Evidence for constraints on contrast: The dispersion theory of contrast. UCLA Working Papers in Phonology 1, ed. by [Chai Sunne Hsu], 86-106.

Flemming, Edward. 2004. Contrast and perceptual distinctiveness. Phonetically-Based Phonology, ed. by [Bruce Hayes, Robert Kirchner, and Donca Steriade], 232-276. Cambridge: Cambridge University Press.

FLEMming, EdWARD. 2006. The role of distinctiveness constraints in phonology. Cambridge: MIT, MS. Online: http://web.mit.edu/flemming/www/dispersion.html

Hayes, Bruce. 1999. Phonetically Driven Phonology: The role of Optimality Theory and Inductive Grounding. Functionalism and Formalism in Linguistics, ed. by [Michael Darnell, Edith A. Moravcsik, Frederick J. Newmeyer, and Kathleen Wheatley], 243-285. Amsterdam/Philadelphia: John Benjamins Publishing Company.

Huffman, Marie K. and RenA A. Krakow (eds.) 1993. Nasals, nasalization, and the velum. Volume 5; (Phonetics and Phonology). London: Academic Press.

Kingston, John. 2007. The phonetics-phonology interface. The Cambridge Handbook of Phonology, ed. by [Paul De Lacy], 401-434. New York: Cambridge University Press.

Instituto SocioAmbiental. 2015. Povos Indígenas no Brasil. 30 November 2015. Online: http://pib.socioambiental.org/

LAPIERRe, Myriam. 2015. The Vowel System of Mebêngôkre. Ottawa, Canada: University of Ottawa, Honour's thesis.

LILJENCRANTS, JOHAN. and LINDBLOM, BJÖRN. 1972. Numerical simulation of vowel quality systems: The role of perceptual contrast. Language 48.839-862.

LindBLOM, BJÖRN. and ENGSTRAND, OLlE. 1989. In what sense is speech quantal? Journal of Phonetics 17.107-121.

LinDBlOM, BJÖRN. 1990. Explaining phonetic variation: A sketch of the H\&H theory. Speech Production and Speech Modeling, ed. by [William J. Hardcastle and Alain Marchal], 403-439. Dordrecht: Kluwer Academic Publishers.

Maddieson, IAN. 1984. Patterns of Sounds. Cambridge: Cambridge University Press.

MAEDA, SHINJI. 1993. Acoustics of vowel nasalization and articulatory shifts in French nasal vowels. In Huffman \& Krakow, 147-167.

SAlAnOvA, ANDRÉS P. 2001. A nasalidade em Mebengokre e Apinayé: o limite do vozeamento soante. São Paulo, Brazil: Universidade Estadual de Campinas, Master's thesis.

SAlanova, Andrés P. and Maria AmÉlia Reis Silva. 2010. Mebengokre (Kayapó). Dictionnaire des langues, ed. by [Emilio Bonvini, Joëlle Busuttil, and Alain Peyraube], 1531-1538. Paris: Presses Universitaires de France.

Schwartz, Jean-Luc; Louis-Jean Bö̈; NATHalie Vallée; and Christian ABry. 1997a. The Dispersion-Focalization Theory of vowel systems. Journal of Phonetics 25.255-286.

Schwartz, Jean-Luc; Louis-Jean Bö̈; NAthalie Vallée; and Christian Abry. 1997b. Major trends in vowel system inventories. Journal of Phonetics 25.233-253.

Schwartzman, Steve. 1987. The Panará of the Xingu Park: The transformation of a society. Chicago, IL: University of Chicago dissertation.

Shosted, Ryan; Christopher CARIgnan; and PANYing Rong. 2012. Managing the distinctiveness of phonemic nasal vowels: Articulatory evidence from Hindi. Journal of the Acoustical Society of America 131.455-465.

Solé, MARIA-JoSEP. 2012. Natural and unnatural patterns of sound change? The Initiation of Sound Change: Perception, production, and social factors, ed. by [Maria-Josep Solé, and Daniel Recasens], 123-146. Amsterdam/Philadelphia: John Benjamins Publishing Company.

Stevens, Kenneth N. 1972. The quantal nature of speech: Evidence from articulatory-acoustic data. Human communication: a unified view, ed. by [E. E. Davis and P. B. Denes], 51-66. New York: McGraw-Hill.

STEVEns, KenNETH N. 1989. On the quantal nature of speech. Journal of Phonetics 17.3-45.

Storto, Luciana R. and Didier Demolin. 2002. Production and perception of Vowels in Karitiana. Journal of the Acoustical Society of America 112.2251.

Stout, Mickey, and Ruth Thomson. 1974. Fonêmica Txukahamei (Kayapó). Série Lingüística 3. Brasilia: SIL. 